\title{
Plenary Speaker Robert Langer Plans to Focus on Biomaterials
}

Robert Langer, Kenneth J. Germeshausen Professor of Chemical and Biomedical Engineering at MIT, will give his plenary presentation on "Biomaterials: New Polymers and Novel Applications" at the 1995 MRS Spring Meeting in San Francisco. The Plenary Session is scheduled for Monday, April 17 at 6 p.m.

In his talk, Langer will emphasize the role materials scientists can play in medical research by intentionally synthesizing materials for medical applications to replace the current process of using offthe-shelf materials to address medical problems. In particular, Langer will discuss the use of degradable polymers to deliver the products of biotechnology, such as proteins, peptides, and gene therapy agents, and the use of bioerodible polymers for tissue engineering.

Langer developed his career on biomaterials since, as a postdoctoral fellow, he was the first to discover premises on which the use of polymers could be used

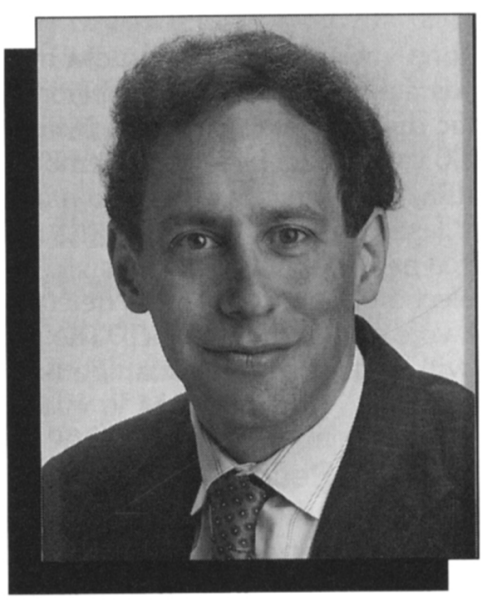

Robert Langer

for the delivery of all molecules with a molecular weight over 500 daltons. From this discovery, he developed an evolution of methods from incorporating molecules into a variety of polymers to finding poly- mers that could be used for the slow delivery of vaccines.

Langer and his students created the field of controlled release. His research sparked investigations by many researchers and companies who now design controlled release systems for macromolecules considered for medical therapy.

Langer's collaborative research efforts further led him to the discovery of polymeric systems used for tissue engineering. This concept resulted in the development of new skin for burn victims and patients with skin ulcers, and the formation of other tissues such as liver and cartilage.

In 1989, Langer was elected to the Institute of Medicine of the National Academy of Sciences, and in 1992 he was elected to both the National Academy of Engineering and to the National Academy of Sciences. He is the only active member of all three U.S. National Academies. He has written 420 articles, 122 patents, and edited 9 books.

\section{MIRS \\ MATERIALS RESEARCH
SOCIETY \\ MATERIALS RESEARCH SOCIETY • SHORT COURSES AND TUTORIALS \\ In Materials Science and Technology for the Applied Scientist and Engineer}

Selected short courses and tutorial covering the latest developments in materials science and technology will be offered in conjunction with the 1995 Spring Meeting of the Materials Research Society. These up-to-date presentations are at the forefront of science and technology and complement Spring Meeting symposium topics. SPECIALTY, REVIEW, AND SURVEY COURSES and TUTORIALS are designed to meet the needs of scientists, engineers, professional staff, and managers who want to know the latest techniques in materials science and technology. For information about registration, student scholarships, and special meeting registration discounts, contact MRS Headquarters: Phone (412) 367-3004 ext. 320; FAX (412) 367-4373

C-07: AMORPHOUS SILICON MATERIALS AND DEVICES

Robert A. Street and Michael Hack, Xerox Palo Alto Research Center Monday, April 17, 8:30 a.m. - 4:30 p.m.

Preregistration ....\$395 On-site ..............\$420 Room Pacific C

C-32: ELLIPSOMETRY FUNDAMENTALS AND APPLICATIONS

Robert W. Collins, Penn State University

Eugene A. Irene, University of North Carolina

Friday, April 21, 8:30 a.m. - 4:30 p.m.

Preregistration ....\$395 On-site .............\$420 Room Pacific A

F-10: FUNDAMENTALS AND APPLICATIONS OF ION BEAM ASSISTED DEPOSITION James K. Hirvonen, U.S. Army Research Laboratory

Thursday, April 20, 8:30 a.m. - 4:30 p.m.

Preregistration ....\$395 On-site ..............\$420 Room Pacific A

M-11: MAGNETIC THIN FILMS: PHYSICS AND APPLICATIONS

Bruce A. Gurney and Ernesto E. Marinero, IBM Almaden Research Center

Thursday, April 20, and Friday, April 21

8:30 a.m. - 4:30 p.m.

Preregistration ....\$595 On-sile ..............\$620 Room Pacific B

M-20: LIGHT-EMITTING POROUS SILICON - FABRICATION, PROPERTIES, AND DEVICE APPLICATIONS

Philippe M. Fauchet, University of Rochester

Tuesday, April 18, 8:30 a.m. - 4:30 p.m.

Preregistration ....\$395 On-site ..............\$420 Room Pacific C

M-21: EPITAXIAL METAL OXIDE FILMS \& HETEROSTRUCTURES DEPOSITION R. Ramesh, Bellcore

Monday, April 17, 8:30 a.m. - 4:30 p.m.

Preregistration ....\$395 On-site ..............\$420 Room Pacific A
P-14: FILM FORMATION, ADHESION, SURFACE PREPARATION, AND CHARACTERIZATION OF THIN-FILM STRUCTURES

Donald M. Mattox, IP Industries

Thursday, April 20 and Friday, April 21

8:30 a.m. - 4:30 p.m.

Preregistration ....\$595 On-site .............\$620 Room Pacific C

P-26: METALLIZATION FOR DEVICES, CIRCUITS, AND PACKAGINGNLSI \& ULSI

Shyham Murarka, Rensselaer Polytechnic institute

Monday, April 17, 8:30 a.m. - 4:30 p.m.

Preregistration ....\$395 On-site ..............\$420 Room Pacific B

TP-06: ELECTROMIGRATION

James R. Lloyd, Digital Equipment Corporation

Monday, April 17, 8:30 a.m. - 12:30 p.m.

Preregistration ....\$95 On-site ..............\$120 Room Pacific J

TP-11: FEDERAL MATERIALS RESEARCH PROGRAMS AND OPPORTUNITIES

Louis lanniello, Consultant (formerly with the Department of Energy)

Tuesday, April 18, 8:30 a.m. - 12:30 p.m.

Preregistration ....\$ 95 On-site .............\$120 Room Pacilic B

TP-12: GROWTH, CHARACTERIZATION AND APPLICATION OF III NITRIDES

Jacques Pankove, Astralux, Inc.

Theodore Moustakas, Boston University

Monday, April 17, 8:30 a.m. - 12:30 p.m.

Preregistration ....\$ 95 On-site ..............\$120 Room Pacilic I

In conjunction with the Materials Research Society's 1995 Spring Meeting (After March 31 , 1995 , short course and tutorial registrations will be $\$ 25$ higher.) 